\title{
Late Glacial-Holocene record of benthic foraminiferal morphogroups from the eastern Arabian Sea OMZ: Paleoenvironmental implications
}

\author{
$\mathrm{K}_{\text {VERMA }}{ }^{1}$, S K Bharti ${ }^{1,2}$ and A D Singh ${ }^{1, *}$ \\ ${ }^{1}$ Center of Advanced Study in Geology, Banaras Hindu University, Varanasi 221 005, India. \\ ${ }^{2}$ Paleontology Div. I CHQ, Geological Survey of India, 15 A \& B Kyd Street, Kolkata 700 016, India. \\ *Corresponding author. e-mail: arundeosingh@yahoo.com
}

MS received 22 July 2016; revised 25 May 2017; accepted 27 May 2017; published online 6 March 2018

The Arabian Sea is characterized today by a well-developed and perennial oxygen minimum zone (OMZ) at mid-water depths. The Indian margin where the OMZ impinges provides sediment records ideal to study past changes in the OMZ intensity and its vertical extent in response to the changes of monsoondriven primary productivity and intermediate water ventilation. Benthic foraminifera, depending upon their adaptation capabilities to variation in sea floor environment and microhabitat preferences, develop various functional morphologies that can be potentially used in paleoenvironmental reconstruction. In this study, we analysed benthic foraminiferal morphogroups in assemblage records of the last 30 ka in a sediment core collected from the lower OMZ of the Indian margin (off Goa). In total, nine morphogroups within two broadly classified epifaunal and infaunal microhabitat categories are identified. The abundance of morphogroups varies significantly during the late Glacial, Deglacial and Holocene. It appears that monsoon wind driven organic matter flux, and water column ventilation governing the OMZ intensity and sea-bottom oxygen condition, have profound influence on structuring the benthic foraminiferal morphogroups. We found a few morphogroups showing major changes in their abundances during the periods corresponding to the northern hemisphere climatic events. Benthic foraminifera with planoconvex tests are abundant during the cold Heinrich events, when the sea bottom was oxygenated due to a better ventilated, weak OMZ; whereas, those having tapered/cylindrical tests dominate during the last glacial maximum and the Holocene between 5 and $8 \mathrm{ka} \mathrm{BP}$, when the OMZ was intensified and poorly ventilated, leading to oxygen-depleted benthic environment. Characteristically, increased abundance of taxa with milioline tests during the Heinrich 1 further suggests enhanced ventilation attributed probably to the influence of oxygen-rich Antarctic Intermediate Water (AAIW).

Keywords. Paleontology; benthic foraminifera; oxygen minimum zone; Arabian Sea.

\section{Introduction}

Seasonally reversing monsoon winds produce seasonal and spatial patterns in the Arabian Sea surface circulation, hydrography and biological productivity. A strong oxygen minimum zone
(OMZ) currently exists in the Arabian Sea at intermediate water depths between 150 and $1250 \mathrm{~m}$ due to a combination of high primary productivity induced large flux of organic matter and poor ventilation of thermocline waters (Wyrtki 1973; Olson et al. 1993). In recent years, the 
temporal variability in the Arabian Sea OMZ on longer to shorter time scales has been a subject of intense research, because of its implications on past changes of biogeochemical cycles and nutrient inventory contributing to global climate change.

The benthic environment within the OMZ, as witnessed today in the Arabian Sea is typified by low-oxygen level and high organic matter content (Paropkari et al. 1993; Calvert et al. 1995). Benthic foraminifera have the potential to serve as indicators of the OMZ intensity, as many of the taxa are considered to be sensitive to changes in ocean-floor oxygen condition. Studies on modern benthic foraminifera indicate that among the various abiotic and biotic factors, trophic (organic carbon flux) and oxygen conditions are the main parameters governing the benthic foraminiferal population, particularly in areas of oxygen depletion and high primary production such as the Arabian Sea margins within the OMZ (e.g., Sen Gupta and Machain-Castillo 1993; Bernhard et al. 1997; Loubere 1997; Jannink et al. 1998; den Dulk et al. 1998, 2000; Schulte et al. 1999; Murray 2000; Bharti and Singh 2013). It is difficult to distinguish the relative effectiveness of these two parameters controlling the distribution of the benthic foraminifera, as both the factors are generally coupled. Variation in benthic foraminiferal assemblage in terms of species diversity and abundance of sensitive species are frequently used as indicators for paleoceanographic reconstruction. Several studies have suggested a high potential of morphologies of foraminiferal tests in paleoenvironmental reconstructions (e.g., Chamney 1976; Corliss 1985; Bernhard 1986; Nigam et al. 2007) in areas where ocean bottom is characterized by high carbon flux and oxygen-poor conditions. The adapted morphogroups developed in response to the environmental stress are expected to be unaltered in both the living and fossil assemblages, as test morphologies are generally not obscured by taphonomic processes (Bernhard 1986), except for a few regions affected by strong bottom water currents. Thus, morphogroup analysis of benthic foraminiferal fossil assemblages can provide valuable information about changes in past oceanbottom environments.

In recent years, a few studies have been carried out to investigate the Quaternary history of the deep water circulation and the OMZ intensity in the Arabian Sea, based primarily on the species abundance variation in benthic foraminiferal assemblages (Hermelin et al. 1995; von Rad et al.
1999; den Dulk et al. 1998, 2000; Schmiedl and Leuschner 2005). These studies were mainly focused on the western and northern regions of the Arabian Sea.

The aim of this work is to use benthic foraminiferal morphogroups to decipher history of past changes in benthic environment of the eastern Arabian Sea margin within the oxygen minimum zone. In this effort, we have made use of existing knowledge on modern foraminiferal ecology, morphology and microhabitat preferences.

\section{Study area}

Surface ocean circulation along the west coast of India is driven by seasonal monsoon winds (Warren 1964; Wyrtki 1973). During the summer monsoon (June-September), winds blow from the southwest towards Asia, the South Equatorial Current (SEC) intensifies, northern branch of which forms the Somali Current as a part of anticyclonic southwest monsoon circulation (Schott and McCreary 2001). In this season, the West Indian Coastal Current (WICC) flows southward along the eastern margin of the Arabian Sea (Shetye et al. 1990; Shetye 1998) and finally joins the eastward flowing Southwest Monsoon Current (SMC) in the southeastern Arabian Sea (Shenoi et al. 1999; Schott and McCreary 2001; Shankar et al. 2002). The strongly stratified water mass forms in summer due to high precipitation and runoff from the Western Ghats (Joseph and Freeland 2005). Weak upwelling occurs along the southwest coast of India (south of $10^{\circ} \mathrm{N}$ ) during this season (Sharma 1966; Wyrtki 1973; Naidu et al. 1999). During winter monsoon (December-March), the wind pattern reverses and a cyclonic circulation develops causing weak, sporadic upwelling along the coasts off Pakistan and India (Colborn 1975; Zhang 1985; Bauer et al. 1991). The cool dry air brought by northeasterly winds in winter intensifies evaporation, leading to surface cooling and vertical mixing in the eastern Arabian Sea (north of $10^{\circ} \mathrm{N}$ ) (Banse and Mc Clain 1986; Madhupratap et al. 1996; Kumar et al. 2000). In this season, the WICC reverses and the Northeast Monsoon Current (NMC) transport waters from the Bay of Bengal (BOB) into the southeastern Arabian Sea up to $13^{\circ} \mathrm{N}$ (Sarma 2002; Shankar et al. 2016).

The water masses in the eastern Arabian Sea are a combination of locally and externally generated water masses (Schott and McCreary 2001). The 


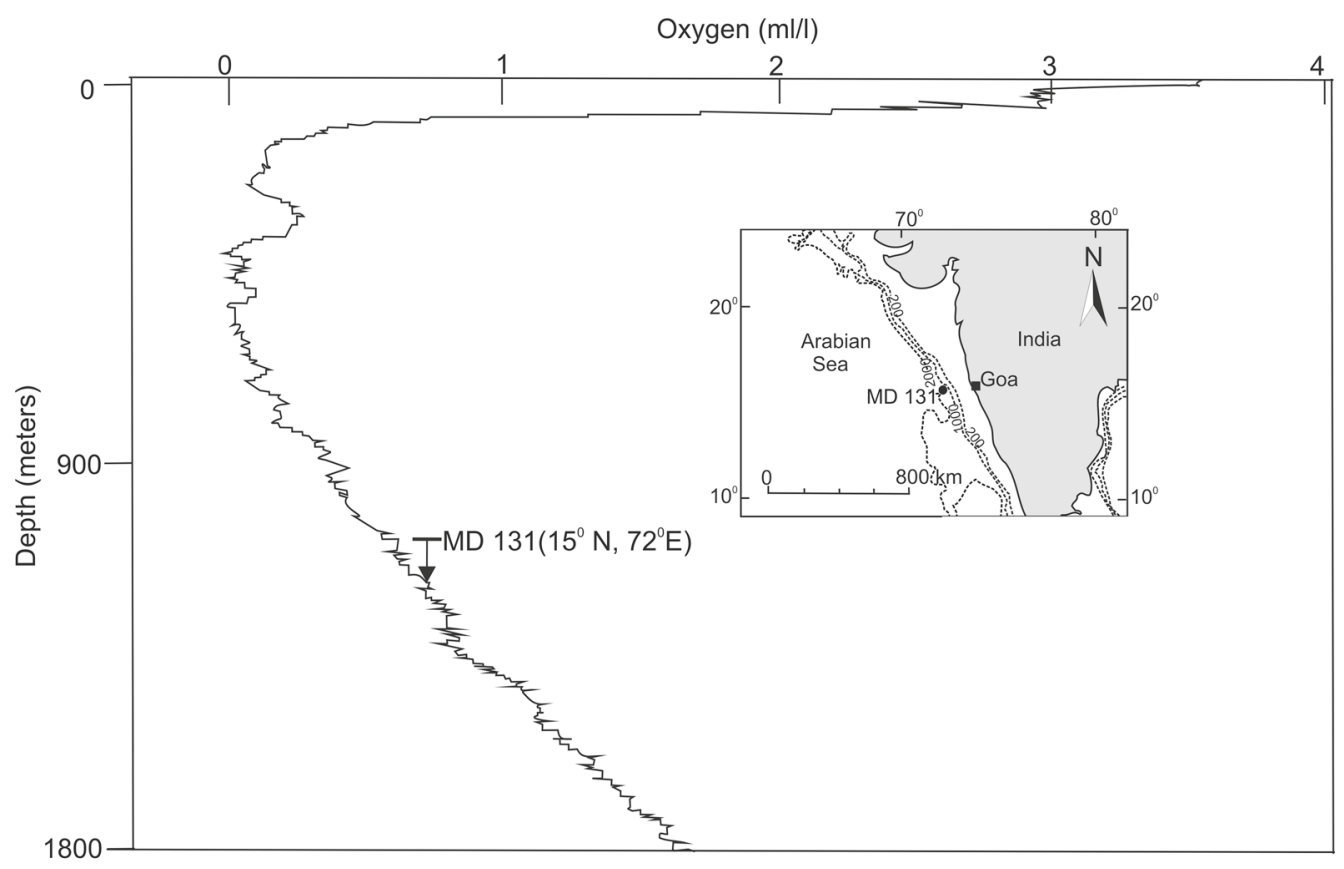

Figure 1. Locations of the sediment core MD 131 (water depth $1230 \mathrm{~m}$ ) (inset) and a vertical profile of oxygen level measured at $11.30^{\circ} \mathrm{N}, 73.30^{\circ} \mathrm{E}$, depicting approx. oxygen conditions at the core site.

high-salinity water (Arabian Sea Water: ASW) is generated in the northern Arabian Sea in winter and spreads southward to the equator with its core at a depth of about $200 \mathrm{~m}$ (Kumar and Prasad 1999; Schott and McCreary 2001). The two high- salinity water masses originating in the Persian Gulf (Persian Gulf Water: PGW) and the Red Sea (Red Sea Water: RSW) flow into the Arabian Sea in the southeasterly direction at about 300 and $500 \mathrm{~m}$ depth, respectively (Schott and McCreary 2001). However, the influence of Arabian Sea Water (ASW) and Persian Gulf Water (PGW) in the eastern Arabian Sea is less evident (Rameshbabu et al. 1980). A low-salinity, oxygen-rich Antarctic Intermediate Water (AAIW) is present in the southern and southeastern Arabian Sea south of $12^{\circ} \mathrm{N}$ (Wyrtki 1971; Sastry and D'Souza 1972; Swallow 1984; Olson et al. 1993; You 1998; Fine et al. 2008). A pronounced oxygen minimum zone (OMZ) exists between 150 and $1250 \mathrm{~m}$ water depths because of high biological productivity, high $\mathrm{O}_{2}$ consumptions and poor ventilation (Wyrtki 1973; Swallow 1984; Caulle et al. 2015).

\section{Methods}

A $9.65 \mathrm{~m}$ long piston core (MD 131) was raised from the central part of the Indian margin (off
Goa) at $1230 \mathrm{~m}$ water depth (figure 1 ). The core site $\left(15^{\circ} 31.8^{\prime} \mathrm{N} ; 72^{\circ} 34.1^{\prime} \mathrm{E}\right)$ is situated at lower boundary of the present day OMZ. The core provides uninterrupted sedimentary sequence of hemi-pelagic mud, free of turbiditic (or mass flow) deposition and reworking, which is characterized by dark coloured indistinctly laminated sediments with intermittently light coloured homogenous facies. The sediment core was sampled at $1-2 \mathrm{~cm}$ intervals. In this study, we used samples up to $3.7 \mathrm{~m}$ core depth at $2-4 \mathrm{~cm}$ intervals. The age model is based on 7 AMS ${ }^{14} \mathrm{C}$ dates (Ivanochko et al. 2005; Singh et al. 2011); and the studied section spans 5-30 kyr. In total, 134 samples were analyzed for benthic foraminifera. For separation of benthic foraminifera tests, approximately $5 \mathrm{~g}$ of dried sediment of each sample was washed through wet sieving over a $63 \mu \mathrm{m}$ screen. Dry residue larger than $63 \mu \mathrm{m}$ was sieved again over a $125 \mu \mathrm{m}$ screen. The $>125 \mu \mathrm{m}$ size fraction was taken for this study. This size fraction is widely used for benthic foraminiferal studies in different areas of world oceans including lowoxygen settings. It is possible that some small sized foraminifera may be abundant in finer fraction $(63-125 \mu \mathrm{m})$. However, the faunal composition, species relative abundances and diversity do not change much, while adding the finer fraction to the coarse size fraction $(>125 \mu \mathrm{m})$ and most of the 
species found in small size fraction also occurred in coarse fraction. Schumacher et al. (2007) and Caulle et al. (2014) have already demonstrated that adding the small size fraction $(63-125 \mu \mathrm{m})$ did not lead to a major change in bathymetric trends in foraminiferal diversity and composition. Furthermore, several studies from the Arabian Sea OMZ regions suggest that benthic assemblages of coarse fraction accurately reflect environmental change (e.g., von Rad et al. 1999; den Dulk et al. 2000; Caulle et al. 2015). The major advantage of selecting $>125 \mu \mathrm{m}$ size fraction is that, for future studies our faunal data would be comparable to the benthic foraminiferal records from other Arabian Sea OMZ regions, which are mainly based on $>125$ or $>150 \mu \mathrm{m}$ size fractions. For qualitative and quantitative benthic foraminiferal analyses, the processed samples were split into sub-samples using
Otto-Splitter to obtain suitable aliquots having about 200-300 specimens. Those samples having less frequent occurrence of benthics were completely used for the separation of tests, even though certain samples contain $<100$ specimens. Five samples containing $<40$ specimens are not considered for data analysis and interpretation (Wollenburg et al. 2007). Presently, the core site is situated well above the foraminiferal lysocline (c. $3300 \mathrm{~m}$; Belyaeva and Burmistrova 1984), and thus dissolution of calcitic foraminiferal tests was expected to be negligible. All specimens were identified under a stereozoom microscope and classified following taxonomic criteria of Loeblich and Tappan (1987, 1992) and Sen Gupta (2002). Benthic foraminifera are again classified into morphogroups as defined by Phleger (1951), Bernhard (1986), Corliss and Chen (1988), Corliss and Fois (1990)

Table 1. Morphogroup classification of benthic foraminifera from the examined core MD 131 as defined by Phleger (1951), Bernhard (1986), Corliss and Chen (1988), Corliss and Fois (1990) and Živković and Babić (2003).

\begin{tabular}{|c|c|c|}
\hline Tapered \& Cylindrical & Spherical & Biconvex \\
\hline Bulimina aculeata* & Cassidulina oblonga & Cancris auriculus \\
\hline Bulimina alazanensis* & Cassidulina subglobosa & Ceratobulimina pacifica \\
\hline Bulimina costata* & Chilostomella ovoidea & Hoeglundina elegans \\
\hline Bulimina marginata* & Lagena hispidula & Lenticulina peregrina \\
\hline Bulimina striata* & Lagena striata & Oridorsalis tenera \\
\hline Bulimina arabiensis* & Pullenia bulloides & Oridorsalis umbonatus \\
\hline Buliminella tenuata* & Sphaeroidina bulloides & Osangularia bengalensis \\
\hline \multicolumn{3}{|l|}{ Chilostomella oolina } \\
\hline Dentalina communis & Planoconvex & Flattened ovoid \\
\hline Dentalina filiformis & Anomalinoides evolutus & Cassidulina carinata \\
\hline Ehrenbergina pacifica & Cibicides marialana gigas & Fissurina sp. \\
\hline Fursenkoina bradyi* & Cibicides mediocris & \\
\hline Fursenkoina bramletti* & Cibicides refulgens & Flattened-tapered \\
\hline Fursenkoina cornuta* & Cibicides robertsonianus & Bolivina pseudobeyrichi* \\
\hline Globobulimina pacifica* & Cibicides wuellerstorfi & Bolivina robusta* \\
\hline Globobulimina pupoides* & Epistominella rugosa & Bolivina subspinescens* \\
\hline Globobulimina pyrula* & Gavelinopsis lobatulus & Vaginulina margaritifera \\
\hline \multicolumn{3}{|l|}{ Lagenodosaria scalaris } \\
\hline Marginulina glabra & Rounded-trochospiral & Milioline \\
\hline Marginulina tenuis & Gyroidinoides aff. orbicularis & Biloculina lucernula \\
\hline Robertina oceanica & Gyroidinoides neosoldanii & Biloculina murrhyna \\
\hline Ruakituria magdalidiforme & & Nummuloculina irregularis \\
\hline Uvigerina porrecta* & Rounded - planispiral & Pyrgo depressa \\
\hline Uvigerina hispida* & Hyalinea balthica & Quinqueloculina lamarckiana \\
\hline Uvigerina-interrupta-costata* & Melonis barleeanum & Quinqueloculina aff. lamarckiana \\
\hline Uvigerina peregrina* & Nonionella miocenica & Quinqueloculina oblonga \\
\hline \multirow[t]{4}{*}{ Uvigerina proboscidea* } & Pullenia quadriloba & Quinqueloculina seminulum \\
\hline & Pullenia subcarinata & Sigmoilina tenuis \\
\hline & Robulus nikobarensis & Sigmoilopsis schlumbergeri \\
\hline & Spirophthalmidium acutimargo & Spiroloculina rotunda \\
\hline
\end{tabular}

*Species referred as rectilinear forms by Nigam et al. (2007). 
and Živković and Babić (2003) using morphological characteristics of tests (table 1). Based on the census data, the relative abundance (\%) of each species and morphogroup category was calculated. We have compared benthic foraminiferal morphogroup records with the published proxy records of primary productivity $\left(\mathrm{C}_{\mathrm{org}} \%\right.$, Singh et al. 2011) and OMZ intensity, oxygen concentration (aragonite\%, Naidu et al. 2014). The methodologies of estimation of $\mathrm{C}_{\text {org }}$ and aragonite contents along with robustness of these proxies for productivity and OMZ reconstructions are discussed in Singh et al. (2011) and Naidu et al. (2014), respectively.

\section{Results}

\subsection{Benthic foraminiferal assemblage records}

A total of 89 species belonging to 51 genera and 34 families of benthic foraminifera are reported. Calcareous benthic foraminifera form the bulk of the foraminiferal population $(>90 \%)$. Agglutinated taxa represented by 11 species of 7 genera and 4 families constitute rest of the benthic foraminiferal assemblage. The calcareous benthic foraminiferal assemblages are composed mainly of buliminid, uvigerinid, bolivinid, cibicidid, miliolid, cassidulinid groups; and Pullenia and Gyroidinoides species (figure 2). Other quantitatively important taxa are Fursenkoina, Oridorsalis and Chilostomella species, Osangularia bengalensis, Sphaeroidina bulloides, Hoeglundina elegans and Melonis barleeanum. Although, benthic foraminiferal abundance records reveal broad changes in the composition of assemblages during the late Glacial, Deglacial and the Holocene periods; prominent changes at millennial scale are noticed during certain intervals corresponding to northern hemispheric climatic events (figure 2). The buliminids account for an average of $28 \%$ of the benthic population in the examined core. The percentage abundance of this group varies between its minimum $5 \%$ and maximum $73 \%$. The main constituent taxa of the buliminid assemblage are $B$. costata, $B$. aculeata and B. alazanensis. Temporal variation in relative abundance of the total buliminids reveals prominent increases between 18 and $23 \mathrm{ka}$ $\mathrm{BP}$ (maximum at $\sim 22.5 \mathrm{ka} \mathrm{BP}$ ), 13 and $14 \mathrm{ka}$ $\mathrm{BP}$ and 5 and $8 \mathrm{ka} \mathrm{BP}$. The abundance of buliminids significantly declined during $15-17.5 \mathrm{ka}$ BP, and 23.5-24.5 ka BP. Cassidulinids is the next important component of the benthic assemblage in the core and Cassidulina carinata and C. subglobosa are the major constituents of the cassidulinid population. Temporal variation pattern of total cassidulinids shows significant variation down-core, with prominent increase in abundance during 2728 ka BP, 17.5-22 ka BP and 5-6 ka BP (figure 2). A considerable decrease in abundance is noticed between 28 and 29 ka BP, 22.5 and $25 \mathrm{ka} \mathrm{BP}$ and 15 and $17 \mathrm{ka}$ BP. Cibicidid population in benthic foraminiferal assemblages is represented by Cibicides marialana gigas, C. mediocris, C. refulgens, $C$. robertsonianus and $C$. wuellerstorfi. The abundance of total cibicidids in the core varies between its maximum $22 \%$ and minimum $0 \%$. The abundance pattern of this group is opposite to that of the buliminids and shows its abundance maxima during 15-17 ka BP and 25-27 ka BP (figure 2). Between 21 and 23 ka BP, this group is characteristically extremely low in its abundance. The miliolids in the examined core are represented mainly by Quinqueloculina, Pyrgo and Biloculina. Miliolids constitute bulk of the porcelaneous tests of benthic population. This group shows remarkable variation in its abundance down-core with maximum during 14.5-17 ka BP and a significant increase between 25 and $30 \mathrm{ka}$ BP (figure 2). The main constituent taxa of uvigerinid population in benthic assemblages are U. interrupta-costata, U. peregrina, U. hisp$i d a$ and $U$. proboscidea. The relative abundance of total uvigerinids in the core varies between $0 \%$ and $23 \%$, with high abundances during 29-30, 23.5$25.5,20.5-21.5,12-13.5 \mathrm{ka} \mathrm{BP}$ and maximum at around 6 ka BP. The periods between 14 and 17.5 ka BP, 22 and 23 ka BP and 26 and 29 ka BP are characterized by a significant decline in its abundance. Bolivina robusta is the only quantitatively significant species of bolivinid population in the examined core. The bolivinid group shows its maximum abundance between 8 and 12 ka BP. Between 17.5 and $30 \mathrm{ka} \mathrm{BP}$, bolivinids are either absent or present with very low abundance. The constituent species of Pullenia are P. bulloides, P. quadriloba and $P$. subcarinata. The abundance record of Pullenia spp. reveals rapid fluctuations down-core on century to millennial scales (figure 2). The prominent increase in abundance occurred between 18 and 22 ka BP; however, Pullenia spp. abundance was conspicuously low during $15-17$ and 23-24.5 ka BP (figure 2). It is interesting to record that since 13 ka BP, pullenids are absent except for a few specimens present in core-top samples. The Gyroidinoides population is composed of two 


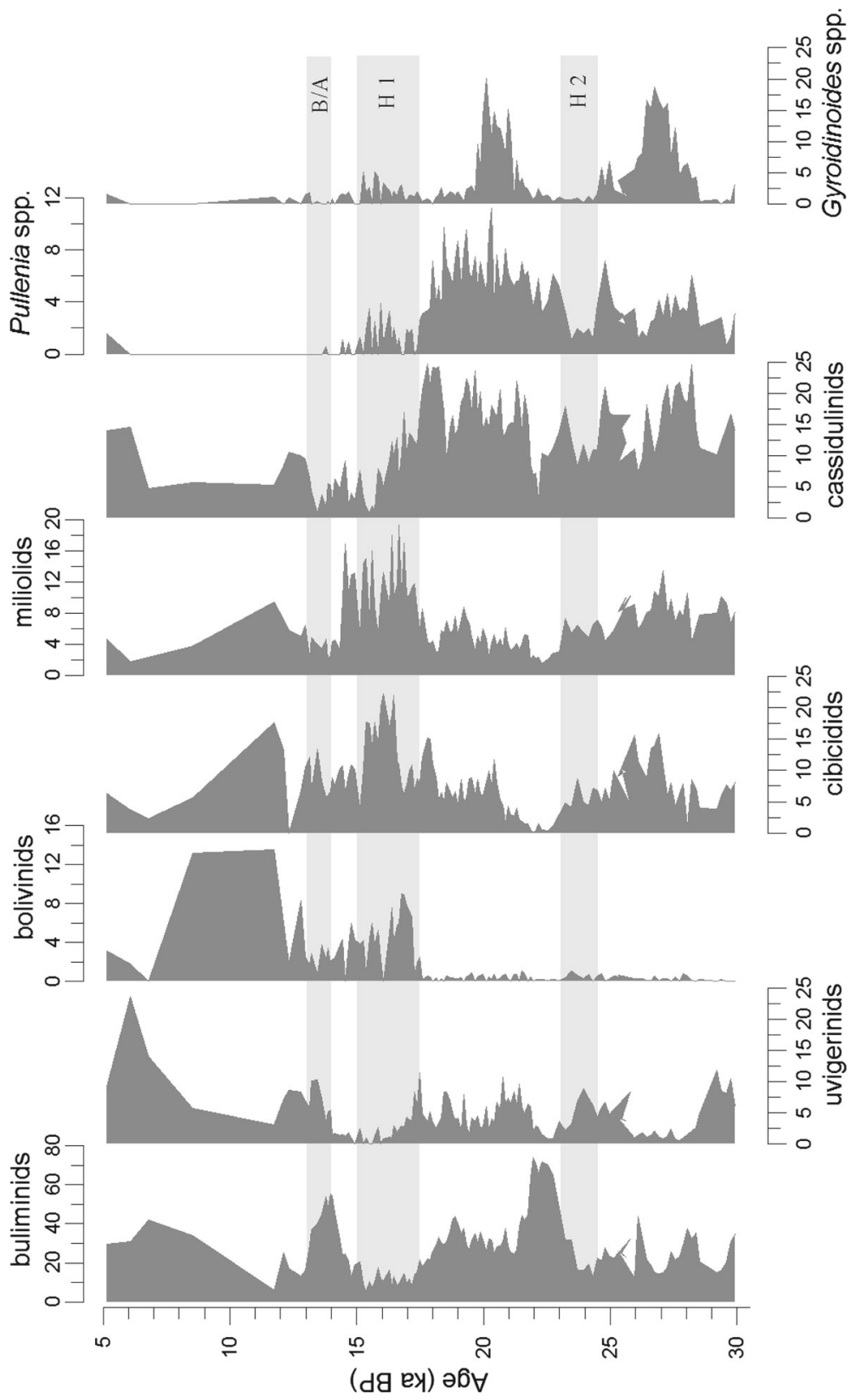

Figure 2. Temporal variations in relative abundances of quantitatively important benthic foraminiferal groups in cores MD 131 (B/A: Bølling/Allerød; H1, H2: Heinrich events).

species, G. aff. orbicularis and G. neosoldenii. The abundance of Gyroidinoides spp. has been very low all through, except for two brief intervals (20-21, 26.5-27.5 ka BP) (figure 2). The abundance pattern of buliminids is opposite to those of cibicidids and miliolids. In general, high abundances of buliminids, cassidulinids and Pullenia spp. together are recorded during the late Glacial period with maxima between 18 and $23 \mathrm{ka} \mathrm{BP}$, as compared to the Deglacial and Holocene periods. The intervals of prominent decline in abundances of these groups and increased abundances of cibicidids and miliolids broadly correspond to the north Atlantic cold Heinrich events. A brief interval of high abundance of buliminids during 13-14 ka BP corresponds to the warm Bølling/Allerød event.

Increased abundance of buliminids, cassidulinids, uvigerinids, bolivinids, fursenkoinids, Gyroidinoides and Pullenia species are generally explained by high rate of organic matter deposition to the sea floor, resulting from high surface primary productivity (Corliss and Fois 1990; Rathburn and 
Corliss 1994; Jorissen et al. 1995; den Dulk et al. 2000). Majority of the constituent species of these groups and genera are also known to be limited to the low-oxygen environment. It has been suggested, however, that certain taxa change their microhabitat preferences in response to varying bottom water oxygen concentrations, thus experiencing a wide range of oxygen limit (e.g., Barmawidjaja et al. 1992). High abundances of cibicidids and miliolids in sediment cores of the northern Arabian Sea OMZ have been attributed to the low organic flux coupled with an oxic benthic environment (e.g., den Dulk et al. 2000). Previous studies also suggested an association of Hoeglundina elegans, Sphaeroidina bulloides, Melonis barleeanum and Oridorsalis species in mesotrophic to eutrophic environments to moderately oxygen depleted condition, whereas Chillostomella species to the highly oxygen deficient condition (Linke and Lutze 1993; Kaiho 1994; Gooday 1994; Kuhnt et al. 1999; Gooday et al. 2000). Osangularia species is known to prefer lowoxygen bottom condition (Jannink et al. 1998).

\subsection{Benthic foraminiferal morphogroup patterns}

The benthic foraminifera based on the distinguishing morphological features (test's shape and coiling) are classified into nine morphogroups (rounded-trochospiral, biconvex, planoconvex, milioline, rounded-planispiral, spherical, flattened ovoid, tapered/cylindrical and flattened-tapered) (table 1). The rounded-trochospiral morphogroup includes species of Gyroidinoides and the planoconvex category consists mainly of Cibicides species. The biconvex morphogroup is represented mainly by Oridorsalis species, Hoeglundina elegans, Ceratobulimina pacifica and Osangularia bengalensis. Quinqueloculina, Biloculina and Spiroloculina species are the important taxa of the milioline category. The rounded-planispiral morphogroup includes mainly Melonis barleeanum, Hyalinea balthica, Robulus nikobarensis, Pullenia species (subcarinata, quadriloba), Nonionella miocenica and Spirothalmidium acutimargo. The predominant forms under tapered or cylindrical category are Bulimina, Uvigerina, Fursenkoina, Dentalina and Globobulimina species; and the flattenedtapered morphogroup mainly includes species of Bolivina and Vaginulina. Sphaeroidina bulloides, Pullenia bulloides, Chilostomella ovoidea and Cassidulina species (oblonga, subglobosa) are kept under the spherical morphogroup. Cassidulina carinata is the important constituent species of flattened ovoid category. SEM illustrations of selected benthic foraminifera representing different morphogroups are provided in figure 3 . The average values of percentage abundance of morphogroups in the examined core are most abundant tapered/ cylindrical (36.55\%) followed by spherical $(14.76 \%)$, planoconvex $(9.67 \%)$, biconvex $(9.09 \%)$, flattenedovoid $(7.61 \%)$, milioline $(6.87 \%)$, roundedplanispiral $(4.76 \%)$, rounded-trochospiral $(3.67 \%)$, and flattened-tapered (1.7\%) tests. The individual morphogroup abundance record exhibits prominent changes down-core on millennial scale (figure 4). In general, tapered/cylindrical tests together with spherical, flattened-ovoid morphogroups predominate the foraminiferal assemblages during late glacial period between 18 and $22.5 \mathrm{ka}$ BP. There has been an increase in abundance of tapered/ cylindrical forms in the Holocene between 5 and $8 \mathrm{ka} \mathrm{BP}$ and 13 and $14.5 \mathrm{ka}$ BP. A rapid increase in abundance of spherical tests is noticed for short spells during 12-13 ka BP and 23.5-24.5 ka BP. Flattened-ovoid tests are almost absent in the Holocene assemblages; whereas, rare occurrence of flattened-tapered tests is noticed in late glacial sediment. The period between 15 and $17.5 \mathrm{ka} \mathrm{BP}$ is characterized by a major decline in abundances of tapered/cylindrical, spherical and flattenedovoid tests. These morphogroups except spherical category also show a significant decrease in their abundances between 23 and $24.5 \mathrm{ka}$ BP. The pattern of variation in abundance of planoconvex tests is opposite to the pattern of tapered/cylindrical tests with abundance maxima of former corresponding to the minima of latter and vice-versa. The milioline and biconvex morphogroups both show major reduction in abundances between 18 and $23 \mathrm{ka}$ BP. Maximum abundance of milioline tests is recorded between 14.5 and 17.5 ka BP. High abundance of bioconvex tests is noticed between 23.5 and 24.5 ka BP. In general, major variations in assemblage with respect to relative abundances of different morphogroups are recorded between 13 and 14.5, 15 and 17.5, 18 and 22.5, 23 and 24.5, and 25 and $28 \mathrm{ka}$ BP. The benthic foraminifera having planoconvex and milioline morphologies are important constituents of assemblages between 15 and $17.5 \mathrm{ka} \mathrm{BP}$, a period corresponding approximately to the Heinrich 1 event. In core MD 131, these two morphogroups along with biconvex group also show their high occurrences during the period equivalent to the Heinrich 2 event (between 23 and $24.5 \mathrm{ka} \mathrm{BP}$ ). Between 25 and $28 \mathrm{ka} \mathrm{BP}$, there has been significant increase in abundances 


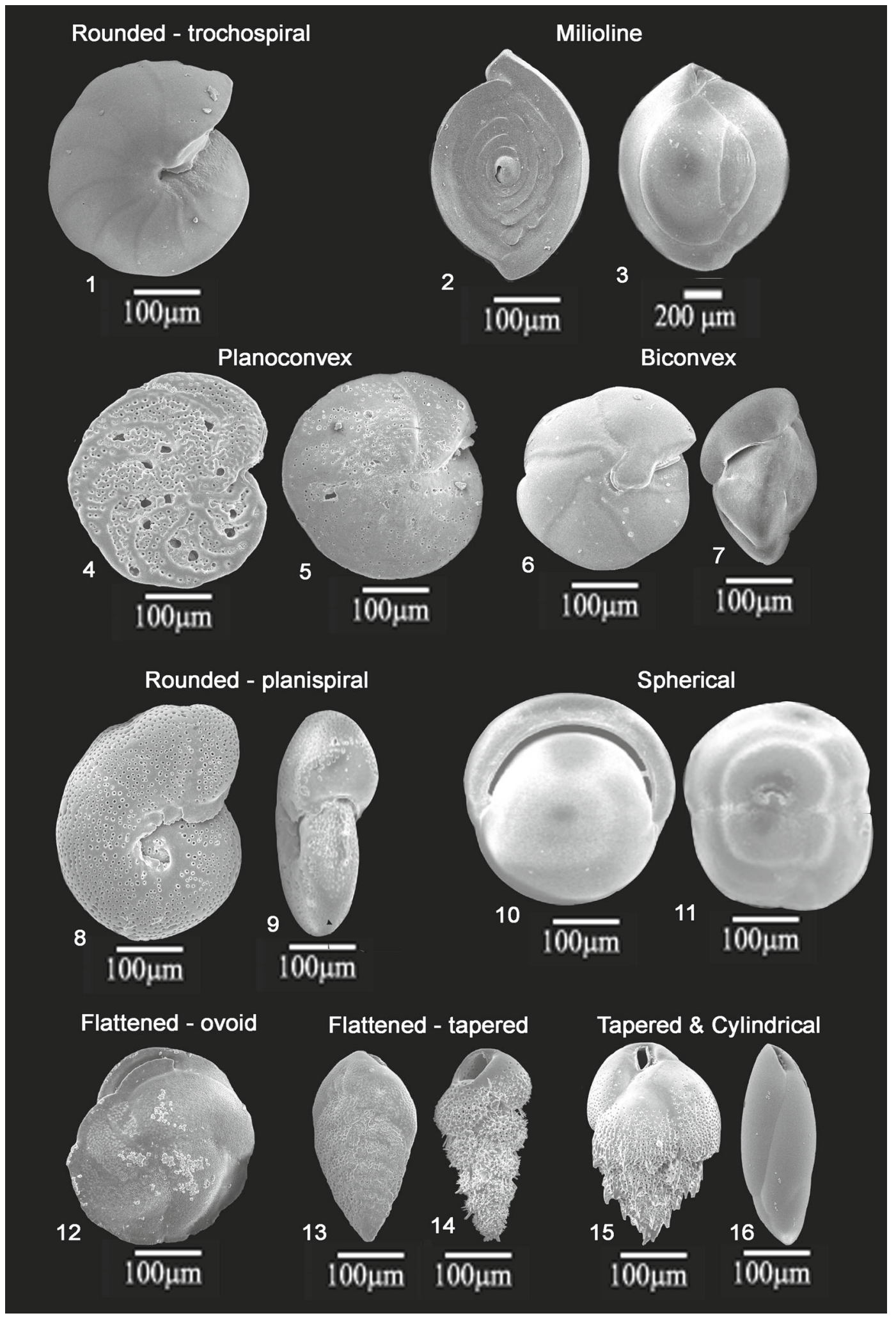

Figure 3. Illustrations of various benthic foraminiferal morphogroup categories. Specimens illustrated are taken from core MD 131. 1. Gyroidinoides orbicularis (d'Orbigny), 2. Spiroloculina rotunda (d'Orbigny), 3. Quinqueloculina seminulum (Linné), 4. Cibicides wuellerstorfi (Schwager), 5. Cibicides marialana gigas (Keijzar), 6. Oridorsalis tenera (Brady), 7. Oridorsalis umbonatus (Reuss), 8-9. Melonis barleeanum (Williamson), 10. Pullenia bulloides (d'Orbigny), 11. Sphaeroidina bulloides (d'Orbigny), 12. Cassidulina carinata (Silvestri), 13. Bolivina robusta (Brady), 14. Bolivina subspinescens (Cushman), 15. Bulimina costata (d'Orbigny), 16. Fuesenkoina bramletii (Galloway and Morrey). 


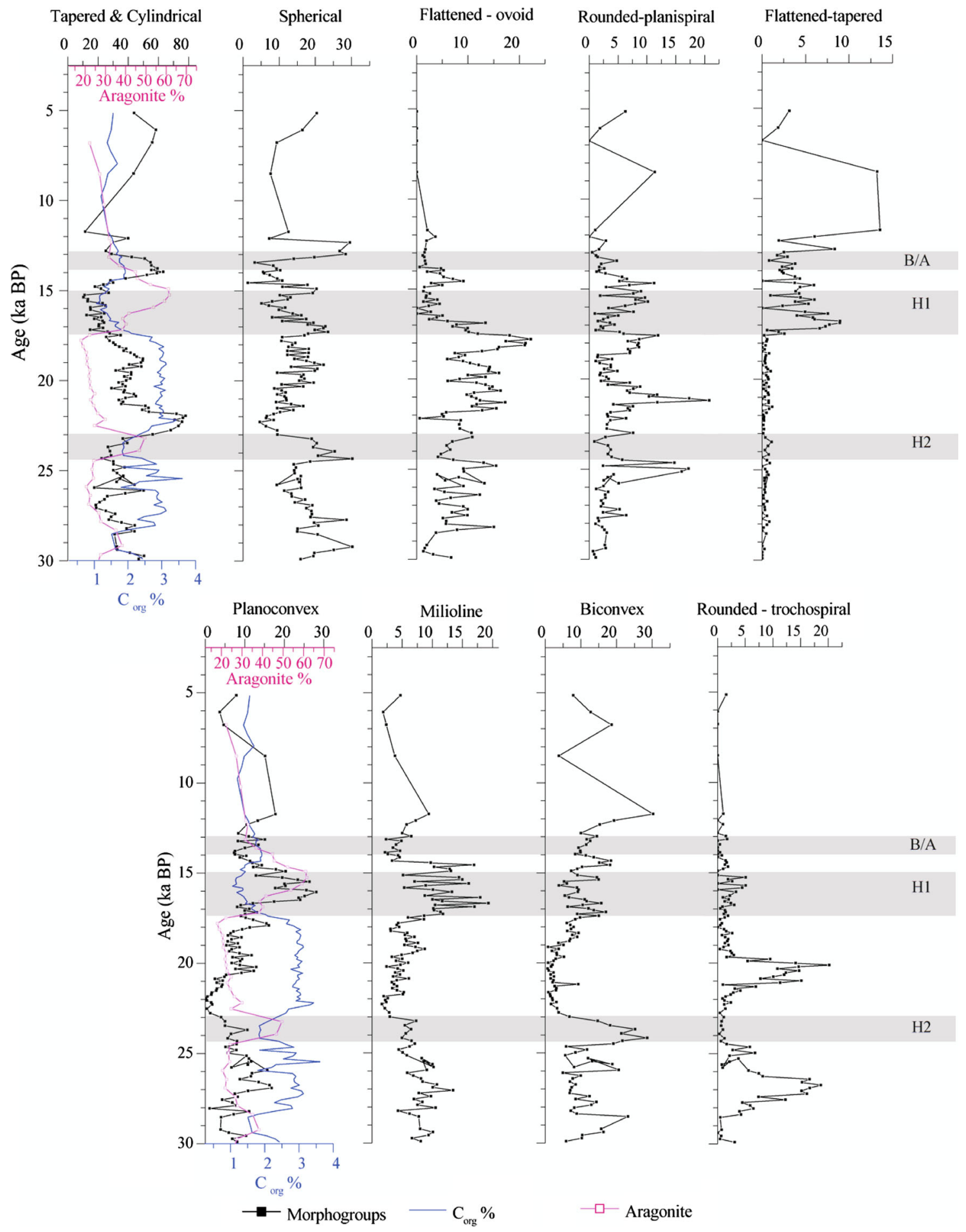

Figure 4. Temporal variation in relative abundances of benthic foraminiferal morphogroups in core MD 131 . The morphogroup abundance records are compared with the records of organic $\mathrm{C}_{\mathrm{org}} \%$ (Singh et al. 2011) and aragonite\% (Naidu et al. 2014). [B/A: Bølling/Allerød; H1, H2: Heinrich events].

of planoconvex, milioline and rounded-trochospiral tests. A peak of abundance of rounded-trochospiral category is also noticed during $20-21$ ka BP. The tapered/cylindrical, spherical and flattened-ovoid morphogroups together predominate the benthic assemblages during the last Glacial maximum between 18 and 22.5 ka BP; whereas, high abundance of tapered/cylindrical tests occurred during the warm Bølling/Allerød event (13-14 ka $\mathrm{BP})$. 


\section{Discussion}

\subsection{Benthic foraminiferal morphogroup as a paleoenvironmental indicator}

Based on the understanding of relationship between modern ecological patterns and faunal distribution, abundances of sensitive species in fossil records are often used for paleoenvironmental reconstructions. The morphologies of fossil benthic foraminifera related to their adaptation capabilities and strategies to changes in ocean bottom environments (e.g., Corliss and Fois 1990), can be potential indicators of paleoenvironments. Recently, Nigam et al. (2007) have used the abundance of rectilinear benthic foraminifera as an index for inferring past sea bottom oxygen conditions in the eastern Arabian Sea. Here, we analyzed the time series records of abundance variations of various benthic foraminiferal morphogroups in order to assess their association with past changes in sea floor environment, with assumption that the responses of benthic foraminifera to bottom conditions and the adapted morphologies as preserved in sediment records have not changed from their living counterparts.

The major changes in abundance records of various morphogroups in the studied core show correspondence with millennial scale northern hemisphere climatic cycles recorded in ice-cores and the north Atlantic sedimentary record (figure 4). Benthic foraminifera with planoconvex, and milioline tests are abundant during the periods equivalent to cold Heinrich event 1 (H1) and biconvex tests are high during Heinrich event 2 (H2). During these time intervals, the abundance of tapered/cylindrical and flattened-ovoid tests declined significantly. The period of Heinrich 1 event is also characterized by a significant reduction in abundance of spherical tests. A major increase in tapered/cylindrical tests abundance occurred during the periods of last glacial maximum (LGM) and warm Bølling/Allerød event. Flattened-ovoid and spherical tests also show their high abundances during the LGM. Proxy records of productivity (planktic foraminifera abundance, organic carbon content) and OMZ intensity (pteropod abundance and aragonite content) from the same core (MD 131) demonstrated significant and rapid changes in primary productivity related export flux of organic matter; and water column ventilation during these climatic events attributed to variations in the OMZ intensity and therefore oxygen condition of benthic environment (Singh et al. 2011; Naidu et al. 2014). Previous studies carried out elsewhere have shown a good relationship between the morphological features of benthic foraminifera and their microhabitat preferences (e.g., Corliss 1985; Corliss and Emerson 1990), although ecological and microhabitat preference of an individual species may vary in different oceanographic settings (e.g., Barmawidjaja et al. 1992; Alve and Bernhard 1995). The benthic foraminiferal microhabitats are classified according to depth at which they live in sediments, viz., epifaunal, shallow infaunal, and intermediate/deep infaunal (Murray 1991; Barmawidjaja et al. 1992; Buzas et al. 1993; Jannink et al. 1998). Foraminifera possessing morphologies featuring high surface area to volume ratio (roundedtrochospiral, biconvex, planoconvex and milioline tests) are suggested to prefer epifaunal habitat; and those having low surface area to volume ratio (flattened, elongated, cylindrical, spherical or roundedplanispiral tests) prefer infaunal microhabitat (e.g., Corliss and Chen 1988).

\subsection{Benthic foraminiferal morphogroup successions}

\subsubsection{Relation to changes in trophic conditions}

We compared our benthic foraminiferal morphogroup records with the $\mathrm{C}_{\text {org }} \%$ record (Singh et al. 2011), a primary productivity proxy (Müller and Suess 1979; Calvert et al. 1995), in order to evaluate if there exists a correspondence between temporal variations in morphogroup and bottom trophic condition in the eastern Arabian Sea in the last $30 \mathrm{ka}$ BP. It is observed that except for some brief intervals (e.g., 26-28 ka BP); high abundance of infaunal morphogroups (tapered/cylindrical, flattened-ovoid and spherical) occurs generally in organic carbon rich sediment, whereas, abundance of epifaunal morphogroups (planoconvex, milioline and biconvex) is high in sediment with relatively low organic carbon content (figure 4). However, this relationship is more clearly seen in patterns of tapered/cylindrical and planoconvex which have opposite trends of variations. With the present data set, it is difficult to explain differences in relationship between abundance variation patterns of epifaunal, infaunal morphogroups and $\mathrm{C}_{\text {org }}$ content during certain intervals such as 26-28 ka BP; for which we require additional geochemical and isotope proxy records. Nevertheless, the organic 
carbon flux to ocean bottom appears to be overall an important parameter structuring these benthic foraminiferal morphogroups. Records of other morphogroups (rounded-planispiral, flattened-tapered and rounded-trochospiral) do not exhibit any definite pattern of association with $\mathrm{C}_{\text {org }}$, however, the reason for this inconsistency cannot be explained by the available data. It is also possible that the factor other than organic carbon, such as intermediate/deep water ventilation through externally sourced water may have influenced the benthic environment and thus overall response of benthic fauna.

\subsubsection{Relation to changes in the oxygen minimum zone intensity}

The development of present day OMZ is attributed to the monsoon-induced high surface water productivity related large export flux of organic carbon and its subsequent decay consuming oxygen in the intermediate waters, combined with a poor ventilation of thermocline waters. The paleoceanographic studies reveal that the OMZ intensity, primary productivity and water column ventilation in the Arabian Sea have varied in the past significantly (Altabet et al. 1995; Reichart et al. 1998; Schulte et al. 1999; Ivanochko et al. 2005; Klöcker et al. 2006). It has been suggested that the intervals of aragonite maxima in sediment records of the Arabian Sea margins were related to the deepening of the ACD due to a weak OMZ (e.g., von Rad et al. 1999; Klöcker et al. 2006; Singh 2007). Recently, Naidu et al. (2014) employing pteropod abundance and aragonite preservation records of the core MD 131, as proxy for the OMZ intensity reconstruction, demonstrated millennial scale changes in the OMZ intensity at the core site in concert with Northern Hemisphere climatic events. The study further revealed that the OMZ was weak during the periods corresponding to the north Atlantic cold Heinrich events (most prominently Heinrich 1 event). We compared records of morphogroup categories with the aragonite $\%$ record to evaluate response of various morphogroups to changes in the OMZ intensity (figure 4). We found that the aragonite maxima indicating a weak OMZ during Heinrich events ( $\mathrm{H} 1$ and $\mathrm{H} 2$ ) correspond to the intervals of major reduction in abundance of tapered/cylindrical tests. On the contrary, the abundance variation pattern of planoconvex tests almost parallels to the pattern of aragonite\%. Therefore, out of nine morphogroups planoconvex (epifaunal) and tapered/cylindrical (infaunal) appear to be more sensitive to the fluctuation in sea bottom oxygen condition associated to the changes in the OMZ intensity (figure 4). The faunal record demonstrates that abundance maxima of planoconvex tests and corresponding low values of tapered/cylindrical tests occur during the Northern Hemisphere cold Heinrich events (H1 and H2) characterized by the low surface productivity, a weak OMZ and oxygenated bottom waters (Singh et al. 2006, 2011; Naidu et al. 2014). However, tapered/cylindrical benthic forms predominate over the species having planoconvex tests during the last glacial maximum and the Holocene between 5 and $8 \mathrm{ka} \mathrm{BP}$, when productivity was high and the OMZ was intensified resulting to an oxygen-depleted sea-bottom environment. The abundance maximum of milioline tests during the interval corresponding to the cold Heinrich 1 event is suggestive of enhanced oxygenation of benthic environment, probably linked to the intensified inflow of oxygen rich southernsourced water. Abundant occurrence of miliolids in the northeastern Arabian Sea cores has been suggested to be associated to the condition of a better ventilated OMZ and an oxygenated benthic environment (Jannink et al. 1998; den Dulk et al. 2000). Several lines of evidence suggest presence of oxygenated southern ocean sourced intermediate waters at the examined core site MD 131 during the Heinrich event 1 (Naidu et al. 2014). Hence, we suppose that these benthic foraminiferal morphogroups have potential in deciphering history of the OMZ evolution, at least in the eastern Arabian Sea.

\subsection{Bottom water oxygenation}

Since the oxygen level of underlying bottom waters is considered as an important parameter governing the microhabitat and related morphological characteristics of benthic foraminifera, we made a broad assessment of past changes in bottom oxygen condition utilizing data available on association of benthic species with sea bottom oxygen level (Appendix). The oxygen sensitive species were grouped into two assemblages broadly associated with (i) oxic environment $\left(\mathrm{O}_{2}:>0.5 \mathrm{ml} / \mathrm{l}\right)$ and (ii) hypoxic environment $\left(\mathrm{O}_{2}:<0.5 \mathrm{ml} / \mathrm{l}\right)$. Record of abundance ratio of oxic to hypoxic assemblage in the core MD 131 demonstrates major change 


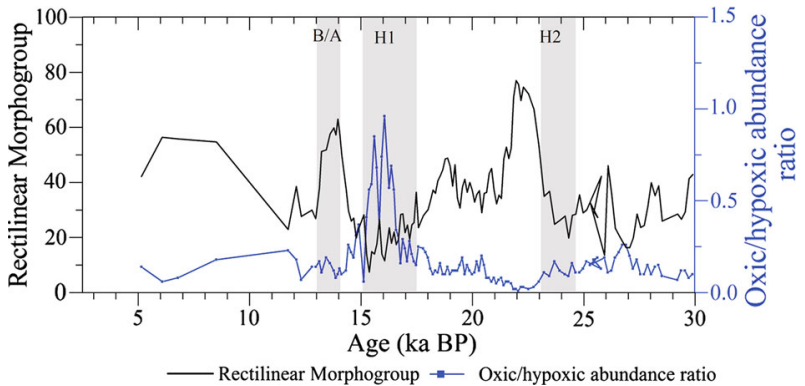

Figure 5. Temporal variation in the oxic/hypoxic benthic foraminiferal abundance ratio; and relative abundance of total rectilinear taxa in core MD 131 [B/A: Bølling/Allerød; H1, H2: Heinrich events].

during Heinrich 1, when oxic taxa dominate the assemblages suggesting high oxygenation of benthic environment (figure 5). It is also evident from the microfaunal that there has been some increase in abundance ratio of oxic/hypoxic taxa for a brief period corresponding to the Heinrich 2 event, but this is not much prominent as compared to the Heinrich 1. Earlier studies suggested low export flux of organic matter associated with weak monsoon circulation, combined with better thermocline ventilation resulting a weakening/breakdown of the OMZ during the Heinrich events, most prominently in Heinrich 1 period (Singh et al. 2006; Singh 2007). It appears that in addition to the reduced primary productivity, intermediate water ventilation was relatively more vigorous during the Heinrich 1, probably linked to the intensification of global deep ocean circulation. This supports the earlier inference drawn based on the pteropod data indicating enhanced ventilation during this period due to intensified inflow of oxygen-rich AAIW (Naidu et al. 2014). Low values of oxic/hypoxic abundance ratio during the last glacial maximum, the Bølling/Allerød and the Holocene between 5 and 8 ka BP point to low oxygen ocean bottom conditions attributed to the monsoon related high organic carbon export flux coupled with poor water column ventilation and an intensified oxygen minimum zone. Recently, Nigam et al. (2007), based on their studies on bathymetric distribution of recent benthic foraminifera in OMZ region off Goa proposed rectilinear forms as proxy for reconstruction of sea bottom oxygen condition. We constructed record of temporal variation in abundance of total rectilinear taxa encountered and compared it with the pattern of our oxic/hypoxic abundance ratio (figure 5). Strikingly, the patterns of variations in both the records match very well with high values of oxic/hypoxic abundance ratio corresponding to low abundances of rectilinear tests and vice versa.

\section{Conclusions}

Records of nine morphogroups identified in benthic foraminiferal assemblages of the cores recovered from the lower boundary of the present day OMZ offshore Goa, reveal major changes in their abundances on millennial scale during the last $30 \mathrm{ka}$. We evaluated the association of foraminiferal morphogroups with monsoon controlled export flux of organic matter and sea bottom oxygen condition related to the OMZ strength. The abundance records of various morphogroups indicate that the patterns of temporal variation in epifaunal planoconvex, milioline and infaunal tapered/ cylindrical categories are related to major changes in sea bottom environment (oxygen and trophic conditions) during the Northern Hemisphere climatic events. The abundance maxima of benthic foraminifera with planoconvex tests indicating oxygenated benthic environment are recorded during the periods equivalent to the cold Heinrich events (H1 and H2) particularly during the Heinrich 1. These were the periods when monsoon related surface productivity was low and the OMZ intensity was weak. A significant increase in abundance of milioline tests during Heinrich 1 event further suggests enhanced ventilation of the OMZ and increased oxygenation of bottom water. The dominance of tapered/cylindrical tests in benthic assemblages during the last glacial maximum, the Bølling/Allerød and the Holocene period between 5 and $8 \mathrm{ka}$ is suggestive of oxygen depleted benthic environment associated to the high surface productivity, poor ventilation of the water column and an intensified OMZ.

\section{Acknowledgements}

This work was supported by the grants from the Indian Space Research Organisation (ISRO-GBP) and the Department of Science and Technology (Project no. SR/S4/ES-30/2002), Government of India, New Delhi. KV thanks the University Grants Commission, New Delhi for the BSR UGC-RFSMS Fellowship. We thank two anonymous referees for their constructive reviews that have helped to improve the manuscript. 


\section{Appendix}

\section{Constituent species of hypoxic $\left(<0.5 \mathrm{ml} / 1 \mathrm{O}_{2}\right)$ and oxic $\left(>0.5 \mathrm{ml} / 1 \mathrm{O}_{2}\right)$ benthic foraminiferal assemblages}

[Data source of benthic faunal association with oxygen concentrations are from Harman 1964; Smith 1964; Douglas and Heitman 1979; Quinterno and Gardner 1987; Mackensen and Douglas 1989; Corliss and Fois 1990; Bernhard 1992; Kaiho 1994, 1999; Jannink et al. 1998; Jorissen et al. 2007; Nigam et al. 2007; Ohkushi et al. 2013; Mazumder and Nigam 2014.]

\section{A1. Hypoxic assemblage}

Bulimina spp., Cassidulina spp., Pullenia spp., Gyroidinoides spp., Uvigerina spp., Oridorsalis spp., Globobulimina spp., Bolivina spp., Fissurina spp., Fursenkoina spp., Dentalina spp., Lagena spp., Hoeglundina elegans, Sphaeroidina bulloides, Buliminella tenuata, Cibicides refulgens, Osangularia bengalensis, Lenticulina peregrina, Melonis barleeanum, Ehrenbergina pacifica, Chilostomella oolina, Nonionella miocenica.

\section{A2. Oxic assemblage}

Cibicides spp. (excluding Cibicides refulgens), Biloculina spp., Quinqueloculina spp., Gavelinopsis lobatulus, Pyrgo depressa.

\section{References}

Altabet M A, Francois R, Murray W D and Prell W L 1995 Climate-related variations in denitrification in the Arabian Sea from sediment ${ }^{15} \mathrm{~N}^{14} \mathrm{~N}$ ratios; Nature $\mathbf{3 7 3}$ 506-509, https://doi.org/10.1038/373506a0.

Alve E and Bernhard J M 1995 Vertical migratory response of benthic foraminifera to controlled oxygen concentrations in an experimental mesocosm; Mar. Ecol. Prog. Ser. 116 137-151.

Banse K and Mc Clain C R 1986 Winter blooms of phytoplankton in the Arabian Sea as observed by the coastal zone color scanner; Mar. Ecol. Prog. Ser. 34 201-211.

Barmawidjaja D M, Jorissen F J, Puskaric S and van der Zwaan G J 1992 Microhabitat selection by benthic foraminifera in the northern Adriatic Sea; J. Foram. Res. 22(4) 297-317.

Bauer S, Hitchcock G L and Olson D B 1991 Influence of monsoonally-forced Ekman dynamics upon surface-layer depth and plankton biomass distribution in the Arabian Sea; Deep-Sea Res. 38 531-553.
Belyaeva N V and Burmistrova I I 1984 Foraminiferal lysocline and critical levels of carbonate sedimentation in the Indian Ocean; Litologiya I Poleznye Iskopaemye 6 57-66 (in Russian).

Bernhard J M 1986 Characteristic assemblages and morphologies of benthic foraminifera from anoxic, organic-rich deposits: Jurassic through Holocene; J. Foram. Res. 16 207-215.

Bernhard J M 1992 Benthic foraminiferal distribution and biomass related to pore-water oxygen content: Central California continental slope and rise; Deep-Sea Res. 39(3/4) 585-605.

Bernhard J M, Sen Gupta B K and Borne P F 1997 Benthic foraminifera proxy to estimate dysoxic bottom-water oxygen concentrations: Santa Barbara Basin, U.S. Pacific continental margin; J. Foram. Res. 27 301-310.

Bharti S K and Singh A D 2013 Bulimina arabiensis, a new of benthic foraminifera from the Arabian Sea; J. Foram. Res. 43 255-261.

Buzas M A, Culver S J and Jorissen F J 1993 A statistical evaluation of the microhabitats of living (stained) infaunal benthic foraminifera; Mar. Micropaleontol. 20 311-320.

Calvert S E, Pedersen T F, Naidu P D and von Stackelberg U 1995 On the organic carbon maximum on the continental slope of the eastern Arabian Sea; J. Mar. Res. 53 269-296. https://doi.org/10.1357/0022240953213232

Caulle C, Koho K A, Mojtahid M, Reichart G J and Jorissen F J 2014 Live (Rose Bengal stained) foraminiferal faunas from the northern Arabian Sea: Faunal succession within and below the OMZ; Biogeosciences 11 1155-1175, https://doi.org/10.5194/bg-11-1155-2014.

Caulle C, Mojtahid M, Gooday A J, Jorissen F J and Kitazato H 2015 Living (Rose-Bengal stained) benthic foraminiferal faunas along a strong bottom-water oxygen gradient on the Indian margin (Arabian Sea); Biogeosciences 12 5005-5019.

Chamney T P 1976 Foraminiferal morphogroup symbol for paleoenvironmental interpretation of drill cutting samples: Arctic America, Albian continental margin; Mar. Sedim., Spec. Publ. 18 585-624.

Colborn J G 1975 The thermal structure of the Indian Ocean; In: International Indian Ocean Expedition Monograph, University of Hawaii Press, Honolulu 2 173p.

Corliss B H 1985 Microhabitats of benthic foraminifera within deep-sea sediments; Nature 314 435-438.

Corliss B H and Chen C 1988 Morphotype patterns of Norwegian Sea deep-sea benthic foraminifera and ecological implications; Geology 16 716-719.

Corliss B H and Emerson S 1990 Distribution of Rose Bengal stained deep-sea benthic foraminifera from the Nova Scotian continental margin and Gulf of Maine; Deep-Sea Res. 37 381-400.

Corliss B H and Fois E 1990 Morphotype analysis of deep sea benthic foraminifera from the northwestern Gulf of Mexico; Palaios 6 589-605.

den Dulk M, Reichart G J, van Heyst S, Zachariasse W J and van der Zwaan G J 2000 Benthic foraminifera as proxies of organic matter flux and bottom water oxygenation? A case history from the northern Arabian Sea; Palaeogeogr. Palaeoclimatol. Palaeoecol. 161 337-359.

den Dulk M, Reichart G J, Memon G M, Roelofs E M B, Zachariasse W J and van der Zwaan G J 1998 Benthic 
foraminiferal response to variations in surface water productivity and oxygenation in the northern Arabian Sea; Mar. Micropaleontol. 35 43-66.

Douglas R G and Heitman H L 1979 Slope and basin benthic foraminifera of the California Borderland; Soc. Econ. Paleontol. Mineral. 27 231-246.

Fine R A, William M S Jr, John L B, Monika R, Dong-Ha M, Mark J W, Alain P and Ray FW 2008 Decadal ventilation and mixing of Indian Ocean waters; Deep-Sea Res. Part I 55 20-37. https://doi.org/10.1016/j.dsr.2007.10.002.

Gooday A J 1994 The biology of deep-sea foraminifera: A review of some advances and their applications in paleoceanography; Palaios 9 14-31.

Gooday A J, Bernhard J M, Levin L A and Suhr S 2000 Foraminifera in the Arabian Sea oxygen minimum zone and other oxygen deficient settings: Taxonomic composition, diversity and relations to metazoan faunas; Deep-Sea Res. Part II 47 25-54.

Harman R A 1964 Distribution of foraminifera in the Santa Barbara Basin, California; Micropaleontol. 10 81-96.

Hermelin J O R and Shimmield G B 1995 Impact of productivity events on benthic foraminiferal fauna in the Arabian Sea over the last 150,000 years; Paleoceanography 10 85116

Ivanochko T S, Ganeshram R S, Brummer G-J A, Ganssen G, Jung S J A, Moreton S G and Kroon D 2005 Variations in tropical convection as an amplifier of global climate change at the millennial scale; Earth Planet. Sci. Lett. 235 302-314.

Jannink N T, Zachariasse W J and van der Zwaan G J 1998 Living (Rose Bengal stained) benthic foraminifera from the Pakistan continental margin (northern Arabian Sea); Deep-Sea Res. Part I 45 1483-1513.

Jorissen F J, de Stigter H C and Widmark J G V 1995 A conceptual model explaining benthic foraminiferal microhabitats; Mar. Micropaleontol. 26 3-15.

Jorissen F J, Fontanier C and Thomas E 2007 Paleoceanographical proxies based on deep-sea benthic foraminiferal assemblage characteristics; In: Developments in Marine Geology (eds) Hillaire-Marcel C andVernal A D, Elsevier, Amesterdam 1 263-325.

Joseph S and Freeland H J 2005 Salinity variability in the Arabian Sea; Geophys. Res. Lett. 32 L09607. https://doi. org/10.1029/2005GL022972.

Kaiho J 1994 Benthic foraminifera dissolved-oxygen index and dissolved-oxygen levels in the modern ocean; Geology 22 719-722.

Kaiho K 1999 Effect of organic carbon flux and dissolved oxygen on the benthic foraminiferal oxygen index (BFOI); Mar. Micropaleontol. 37 67-76.

Klöcker R, Ganssen G Jung S J A, Kroon D and Henrich R 2006 Late Quaternary millennial-scale variability in pelagic aragonite preservation off Somalia; Mar. Micropaleontol. 59 171-183.

Kuhnt W, Hess S and Jian Z 1999 Quantitative composition of benthic foraminiferal assemblages as a proxy indicator for organic carbon flux rates in the South China Sea; Mar. Geol. 156 123-127.

Kumar S P and Prasad T G 1999 Formation and spreading of Arabian Sea high- salinity water mass; J. Geophys. Res. 104(C1) 1455-1464.
Kumar S P, Madhupratap M, Kumar M D, Gauns M, Muraleedhran P M, Sarma V V S S and De Souza S N 2000 Physical control of primary productivity on a seasonal scale in central and eastern Arabian Sea; Proc. Ind. Acad. Sci. (Earth Planet. Sci.) 109 433-441.

Linke P and Lutze G F 1993 Microhabitats preferences of benthic foraminifera-A static concept or a dynamic adaptation to optimize food acquisition? Mar. Micropaleontol. 20 215-234.

Loeblich A R and Tappan H 1987 Foraminiferal genera and their classification; Van Nostrand Rienhold Company, New York 2V 1182.

Loeblich A R and Tappan H 1992 Present status of foraminiferal classification; In: Studies in Benthic Foraminifera (eds) Takayanagi Y and Saito T, Tokai University Press, Tokyo, pp. 93-102.

Loubere P 1997 Benthic foraminiferal assemblage formation, organic carbon flux and oxygen concentrations on the outer continental shelf and slope; J. Foram. Res. 2793 100.

Mackensen A and Douglas R G 1989 Down-core distribution of live and dead deep-water benthic foraminifera in box cores from the Weddell Sea and the California continental borderland; Deep-Sea Res. 36 879-900.

Madhupratap M, Kumar S P, Bhattathiri P M A, Kumar M D, Raghukumar S, Nair K K C and Ramaiah N 1996 Mechanism of the biological response to winter cooling in the northeastern Arabian Sea; Nature 384 549-552.

Mazumder A and Nigam R 2014 Bathymetric preference of four major genera of rectilinear benthic foraminifera within oxygen minimum zone in Arabian Sea off central west coast of India; J. Earth Syst. Sci. 123 633-639.

Müller P J and Suess E 1979 Productivity, sedimentation rate and organic matter in the oceans. I: Organic carbon preservation; Deep-Sea Res. 26 1347-1362, https://doi. org/10.1016/0198-0149(79)90003-7.

Murray JW 1991 Ecology and Paleoecology of Benthic Foraminifera; Longman, Harlow, 397p.

Murray J W 2000 When does environmental variability become environmental change? The proxy record of benthic foraminifera; In: Environmental Micropaleontology (ed.) Martin R E, Topics in Geobiology, Kluwer Academic/Plenum Publishers, New York 15 7-37.

Naidu P D, Ramesh Kumar M R and Ramesh Babu V 1999 Time and space variations of monsoon upwelling along the west and east coasts of India; Cont. Shelf. Res. 19 559-572.

Naidu P D, Singh A D, Ganeshram R S and Bharti S K 2014 Abrupt climate-induced changes in carbonate burial in the Arabian Sea: Causes and consequences; Geochem. Geophys. Geosyst. 15(1) 1398-1406, https://doi.org/10. 1002/2013GC005065.

Nigam R, Mazumder A, Henriques P J and Saraswat R 2007 Benthic foraminifera as proxy for oxygen-depleted conditions off the central west coast of India; J. Geol. Soc. India 70 1047-1054.

Ohkushi K, Kennett J P, Zeleski C M, Moffitt S E, Hill T M, Robert C, Beaufort L and Behl R J 2013 Quantified intermediate water oxygenation history of the NE Pacific: A new benthic foraminiferal record from Santa Barbara basin; Paleoceanography 28 453-467, https://doi.org/10. 1002/palo.20043. 
Olson D B, Hitchcock G L, Fine R A and Warren B A 1993 Maintenance of the low-oxygen layer in the central Arabian Sea; Deep-Sea Res. Part II 40 673-685.

Paropkari A L, Prakash Babu C and Mascarenhas A 1993 New evidenced preservation of organic carbon in contact with oxygen minimum zone on the western continental slope of India; Mar. Geol. 111 7-13.

Phleger FB 1951 Ecology of foraminifera, northwest Gulf of Mexico, Part 1: Foraminifera distribution; Geol. Soc. Am. Memoir 46 1-88.

Quinterno P J and Gardner J V 1987 Benthic foraminifers on the continental shelf and upper slope, Russian River area, northern California; J. Foram. Res. 17 132-152.

Rameshbabu V, Varkey M J, Kesava Das V and Gouveia A D 1980 Water masses and general hydrography along the west coast of India during early March; Ind. J. Mar. Sci. 9 982-989.

Rathburn A E and Corliss B H 1994 The ecology of living (stained) deep-sea benthic foraminifera from the Sulu Sea; Paleoceanography 9 87-150.

Reichart G L, Lourens L J and Zachariasse W J 1998 Temporal variability in the northern Arabian Sea oxygen minimum zone (OMZ) during the last 225,000 years; Paleoceanography 13 607-621.

Sarma V V S S 2002 An evaluation of physical and biogeochemical processes regulating perennial suboxic conditions in the water column of the Arabian Sea; Global Biogeochem. Cycles 16 29.1-29.11.

Sastry J S and D'Souza R N 1972 Oceanography of the Arabian Sea during southwest monsoon. Part II: Stratification and circulation; Ind. J. Mar. Sci. 22 33-34.

Schmiedl G and Leuschner D C 2005 Oxygenation changes in the deep western Arabian Sea during the last 190,000 years: Productivity versus deep water circulation; Paleocenography 20 PA2008, https://doi.org/10. 1029/2004PA001044.

Schott F A and McCreary J P 2001 The monsoon circulation of the Indian Ocean; Progress in Oceanography 51 1-123.

Schulte S, Rostek F, Bard E, Rullkötter J and Marchal O 1999 Variations of oxygen-minimum and primary productivity recorded in sediments of the Arabian Sea; Earth Planet. Sci. Lett. 173 205-221.

Schumacher S, Jorissen F J, Dissard D, Larkin K E and Gooday A J 2007 Live (Rose Bengal stained) and dead benthic foraminifera from the oxygen minimum zone of the Pakistan continental margin (Arabianm Sea). Mar. Micropaleontol. 62 45-73, https://doi.org/10.1016/ j.marmicro.2006.07.004

Sen Gupta B K 2002 Systematics of modern foraminifera; In: Modern Foraminifera (ed.) Sen Gupta B K, Kluwer Academic Publishers Dordrecht, pp. 7-36.

Sen Gupta B K and Machain-Castillo M L 1993 Benthic foraminifera in oxygen-poor habitats; Mar. Micropaleontol. 20 183-201.

Shankar D, Vinayachandran P N and Unnikrishnan A S 2002 The monsoon currents in the north Indian Ocean; Progr. Oceanogr. 52 63-120.

Shankar D, Remya R, Vinayachandran P N, Chatterjee A and Behera A 2016 Inhibition of mixed-layerdeepening during winter in the northeastern Arabian Sea by the West India Coastal Current; Climate Dynam. 47(3-4) 1049-1072, https://doi.org/10.1007/s00382-015-2888-3.

Sharma G S 1966 Thermocline as an indicator of upwelling; J. Mar. Biol. Assoc. India 8 8-19.

Shenoi S S C, Shankar D and Shetye S R 1999 On the sea surface temperature high in the Lakshadweep Sea before the onset of the southwest monsoon; J. Geophys. Res. 104 $15,703-15,712$.

Shetye S R, Gouveia A D, Shenoi S S C, Sundar D, Michael G S, Almeida A M and Santanam K 1990 Hydrography and circulation off the west coast of India during southwest monsoon; J. Mar. Res. 48 359-378.

Shetye S R 1998 West India coastal current and Lakshadweep High/Low; Sadhana 23(5-6) 637-651.

Singh A D 2007 Episodic preservation of pteropods in the eastern Arabian Sea: Monsoonal change, oxygen minimum zone intensity and aragonite compensation depth; Ind. J. Mar. Sci. 36 378-383.

Singh A D, Kroon D and Ganeshram R S 2006 Millennial scale variations in productivity and OMZ intensity in the eastern Arabian Sea; J. Geol. Soc. India 68369 377 .

Singh A D, Jung S J A, Darling K, Ganeshram R, Ivanochko T S and Kroon D 2011 Productivity collapses in the Arabian Sea during glacial cold phases; Paleoceanography 26 PA3210, https://doi.org/10.1029/2009PA001923.

Smith P B 1964 Recent foraminifera off central America. Ecology of benthic species; USGS Prof. Paper 429B $1-55$.

Swallow J C 1984 Some aspects of the physical oceanography of the Indian Ocean; Deep-Sea Res. 30 639-650.

von Rad U, Schulz H, Riech V, den Dulk M, Berner U and Sirocko F 1999 Multiple monsoon-controlled breakdown of oxygen-minimum conditions during the past 30,000 years documented in laminated sediments of Pakistan; Palaeogeogr. Palaeoclimatol. Palaeoecol. 152 129-161.

Warren B A, Stommel H and Swallow J C 1966 Water masses and patterns of flow in the Somali Basin during the southwest monsoon of 1964; Deep-Sea Res. 13 825-860.

Wollenburg J E, Mackensen A and Kuhnt W 2007 Benthic foraminiferal biodiversity response to a changing Arctic palaeoclimate in the last 24,000 years; Palaeogeogr. Palaeoclimatol. Palaeoecol. 255 195-222.

Wyrtki K 1971 Oceanographic Atlas of the International Indian Ocean Expedition; Natl. Sci. Found. Arlington, Washington, 531p.

Wyrtki K 1973 Physical oceanography of the Indian Ocean; In: The Biology of the Indian Ocean (eds.) Zeitschel B and Gerlach SA, Springer, Berlin, pp. 18-36.

You Y 1998 Intermediate water circulation and ventilation of the Indian Ocean derived from water-mass contributions; J. Mar. Res. 56(5) 1029-1067.

Zhang J 1985 Living planktonic foraminifera from the eastern Arabian Sea; Deep-Sea Res. 32 789-798.

Živković S and Babić L 2003 Palaeoceanographic implications of smaller benthic and planktonic foraminifera from the Eocene Pazin Basin (Coastal Dinarides, Croatia); Facies 49 49-60. 